\title{
The relationship between biodiversity and disease transmission risk
}

This article was published in the following Dove Press journal:

Research and Reports in Biodiversity Studies

25 March 2015

Number of times this article has been viewed

\author{
Miriam Pfäffle \\ Nina Littwin \\ Trevor N Petney \\ Department of Ecology and \\ Parasitology, Zoological Institute, \\ Karlsruhe Institute of Technology, \\ Karlsruhe, Germany
}

Correspondence: Miriam Pfäffle Department of Ecology and Parasitology, Zoological Institute, Karlsruhe Institute of Technology, Kornblumenstraße 13,

716131 Karlsruhe, Germany

Tel +49 72I 6084270 I

Email miripfaeffle@web.de

\begin{abstract}
A healthy ecosystem is sustainable, meaning that it has the ability to maintain its structure and functions over time. Past definitions concerning the health of an ecosystem included, among others, both the diversity and complexity of the system, meaning that a healthy ecosystem is a diverse one. In the last decade, researchers have started to focus more on the importance of biodiversity for the distribution and maintenance of diseases in ecosystems, and therefore the ecosystems' role for human health. Based on a vector-borne model of Lyme disease, it was claimed that with a higher biodiversity of non-reservoir hosts for a pathogen, transmission events and infection risk would become reduced, called the dilution effect. This was further adapted for other vector-borne and nonvector-borne diseases, providing evidence for both the absence and the presence of the dilution effect in the wild. Until now, there is still a large lack of knowledge about the mechanisms driving disease transmission in the wild. The aim of this review is to provide insight into disease systems that were studied in relation to biodiversity and disease transmission risk. Furthermore, we discuss methods and strategies which are necessary to improve our understanding of the impact of biodiversity on disease systems and to help fill the existing gaps in our current knowledge.
\end{abstract}

Keywords: dilution effect, Lyme disease, rescue effect, West Nile virus, hantavirus

\section{Introduction}

A healthy ecosystem is sustainable and is able to maintain its functions and structure. The past definitions of the health of an ecosystem included among others health as the absence of disease and health as diversity and complexity. ${ }^{1}$ After the Convention on Biological Diversity of the United Nations, ${ }^{2}$ biodiversity is defined as "the variability among living organisms from all sources including inter alia, terrestrial, marine and other aquatic ecosystems and the ecological complexes of which they are part: this includes diversity within species, between species and of ecosystems." Diversity can be characterized in three different ways: 1) by the number of different entities (eg, species richness); 2) by the relative abundance of different entities (eg, species evenness); and 3) by the specific identities of different entities (community composition). ${ }^{3}$ In ecosystems, biodiversity acts as a regulator of ecosystem processes, as a final ecosystem service, and as something of value for humans. ${ }^{4}$ Therefore, ecosystem properties depend to a large extent on biodiversity regulating the ecological functions of different organisms within the system and the distribution of those organisms over space and time. ${ }^{5}$ Over the last decade, it has become clear that parasites and disease agents can play an important role in the regulation of ecosystem functioning. Infection with echinostome trematodes, for example, influences the burrowing behavior of the bivalve Austrovenus 
stutchburyi and leads to an increase in the biodiversity in marine intertidal environments in New Zealand. ${ }^{6}$ Conversely, the loss of biodiversity may open the way for increased pathogen activity. Knops et $\mathrm{al}^{7}$ demonstrated that the loss of primary producer diversity affects fundamental ecosystem processes including the spread of plant fungal diseases. In addition, invasive hosts and pathogens can induce a loss of biodiversity in natural ecosystems. ${ }^{8}$

By altering the behavior of their hosts, parasites can influence the competitive relationships between different nonparasite species. ${ }^{9}$ The direct impact of parasites on their hosts can lead to alterations in the abundance or population density of the latter and might decrease the importance of these very hosts with regard to interspecies competition or predatorprey-related interactions. ${ }^{10}$ Moreover, the biomass of parasites can even extend that of top predators and other animal groups, implying a high impact on infectious processes in such ecosystems. ${ }^{11}$ In terms of human health and well-being, biodiversity is considered to be critical, with four major biodiversity drivers of human health. These are the quality of life, medical and genetic resources, ecosystem services (benefits that humans receive from ecosystems), and constraints on infectious diseases (high biodiversity decreases the spread of diseases, while decreasing biodiversity may accelerate the spread of disease to human populations). ${ }^{12}$

Although species can become extinct naturally, the rate of extinction has been accelerated due to human intervention in ecosystems by a factor of approximately $1,000-10,000 .{ }^{13}$ The main driving forces behind the increased extinction rate are considered to be human population growth and socioeconomic development resulting in changes in land use, and therefore habitat fragmentation, overexploitation or destruction, pollution, biotic changes, the introduction of new species, and climate change. ${ }^{14}$ The worldwide extinction crisis is accepted by the scientific community, and various strategies to reverse these trends have been elaborated in scientific journals and at meetings, ${ }^{15}$ also with respect to human health.

In 2000, Ostfeld and Keesing ${ }^{16,17}$ created the concept of "dilution effect" on the basis of the exposure risk of humans to Borrelia burgdorferi sensu lato, the agent of Lyme disease. The dilution effect predicts that infection rates among vectors, and ultimately human infection risk, will be lower in highly diverse host communities where non-competent hosts dilute rates of disease transmission between vectors and highly competent hosts. ${ }^{18}$ In contrast, the "rescue effect" (amplification effect) claims that if several species tend to be highly competent reservoirs, high species diversity may actually increase disease prevalence. ${ }^{18}$ Additionally, ecosystems with a naturally high biodiversity might be the source of, or provide, a platform for the emergence of new pathogens. ${ }^{19}$ Obviously, the epidemiology of such diseases is very complex, and the biodiversity of an ecosystem is only part of this complexity. Nevertheless, in order to understand disease transmission, it is important to study the processes and factors responsible for it.

Our aim is to review certain disease systems that have been studied to determine the relationship between biodiversity and disease transmission risk. We try to reveal the complexity of such disease systems and emphasize possible gaps in our knowledge. Furthermore, we discuss the methods and strategies which are necessary to improve the understanding of the impact of biodiversity on disease systems.

\section{Biodiversity and vector-borne diseases}

In order for a vector-borne disease to meet the requirements of the dilution effect, the following assumptions made by Ostfeld and Keesing ${ }^{17}$ must be fulfilled: i) the feeding habits of the vector have to be generalized, which means that the vector must be able to feed on a variety of different hosts, independent of their reservoir competence. ii) Infection of a vector with a pathogen has to be acquired through a host and not transovarially. iii) The reservoir competence among hosts must vary, differentiating between highly competent and non- or less competent hosts. iv) Highly competent hosts have to be the dominant species in the host community, as defined by the proportion of the vector population fed by that species.

\section{White-footed mice, ticks, and Lyme disease}

Since the hypothesis of both the dilution and the rescue effect emerged from the studies carried out by Ostfeld and Keesing, ${ }^{16,17}$ it is only suitable to start with their study on Lyme disease in the USA. In North America, Lyme disease is caused by B. burgdorferi sensu stricto, a spirochete transmitted by the black-legged ticks Ixodes scapularis along the east coast and Ixodes pacificus in the west. The annual reported incidence of Lyme disease in the USA from 2003 to 2012 lay approximately between 19,800 and 30,000, although recent estimates by the Centers for Disease Control suggest that the real number is closer to $300,000 .{ }^{20}$ The cases are concentrated mainly in the northeast and upper Midwest of the USA. ${ }^{20}$ White-footed mice (Peromyscus leucopus), eastern chipmunks (Tamias striatus), and white-tailed deer 
(Odocoileus virginianus) play important roles in the life cycle of I. scapularis and in the epidemiology of B. burgdorferi s.s. While larvae and nymphs feed predominantly on small mammals and birds, adults prefer deer as their hosts. ${ }^{21}$ P. leucopus, a species that is widespread and locally abundant, is believed to be the most competent reservoir host for B. burgdorferi s.s. and is assumed to be responsible for most spirochete infections in larvae in some regions. ${ }^{21}$ Infected mice have a $40 \%-80 \%$ chance of transmitting their infection to an uninfected larva. ${ }^{22}$ The infected larvae overwinter and molt into nymphs, which retain the infection and are the most likely life history stage to use a human as a host. An overlook about the eco-epidemiology of Lyme disease in the USA is given in Figure 1.

A computer simulation model by Van Buskirk and Ostfeld $^{23,24}$ that was parameterized for I. scapularis and its host communities, consisting of one competent and various less competent reservoir hosts, showed that increasing host diversity (both richness and evenness) reduced the infection risk for humans with $B$. burgdorferi s.s. Ostfeld and Keesing $^{16}$ tested the connection between Lyme disease incidences in the eastern part of the USA and the species richness of small mammals, various bird species that nest or forage on the ground, and lizards using a stepwise multiple regression. The three host groups represent the major host groups that are constantly available for ticks. They found negative relationships between Lyme disease incidence and the species richness of small mammals and lizards (dilution effect) and a positive relationship with bird species richness (rescue effect). This large-scale study was supported by Schmidt et al's ${ }^{25}$ analysis of the effect of the population densities of the two main hosts (white-footed mice and eastern chipmunks) on juvenile I. scapularis. The greater the evenness between these two host species, the more the abundance of ticks on mice was reduced resulting in a dilution effect of chipmunks on mice. However, chipmunks are also competent reservoirs for B. burgdorferi s.s.; therefore, high densities of both mice and chipmunks are less likely to decrease infection risk for humans. To support the dilution effect on a smaller scale, Schmidt and Ostfeld ${ }^{26}$ estimated its magnitude in four sites in the eastern New York State, USA. They found that the prevalence of B. burgdorferi s.s. in questing nymphs and adults was much lower than expected if the ticks fed predominantly on highly competent reservoirs. Using an empirically based model, they predicted that at least $61 \%$ of tick blood meals must therefore be provided by alternative hosts. A study by Allan et $\mathrm{al}^{27}$ showed that anthropogenic influences such as forest fragmentation lead to a decrease in biodiversity in small forest patches, followed by increases in the density of white-footed mice and the prevalence of Borrelia-infected

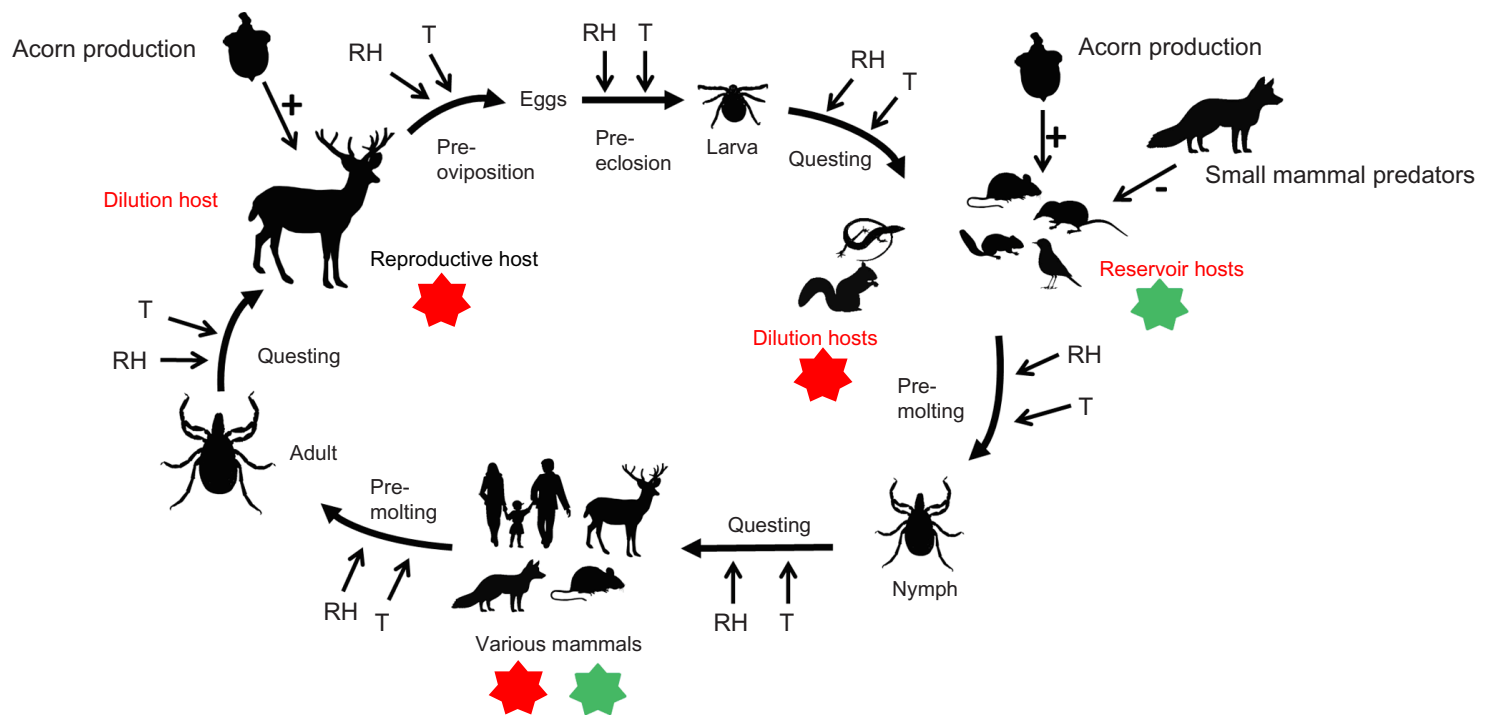

Figure I Eco-epidemiology of Lyme disease in the USA including both abiotic and biotic factors that influence hosts or the vector tick Ixodes scapularis.

Notes: The start of tick activity, questing duration, and interstadial development (pre-oviposition, pre-eclosion, pre-molting) depend on the ambient temperature and relative humidity, which influence water loss, the total generation time, and the proportion of ticks that die before reproduction. ${ }^{47}$ Host densities of the most important hosts of $I$. scapularis, deer, and mice are influenced by mast years and predator densities. Transovarial transmission of Borrelia spirochetes is rare; main transmission routes are transstadial and by feeding on an infected host. The main host of adult ticks is white-tailed deer which acts as a dilution host for Borrelia burgdorferi sensu lato but as a reproductive host for the tick population. Larvae feed on a variety of smaller hosts that act either as reservoir hosts for B. burgdorferi s.l. (mice, shrews, chipmunks) or as dilution hosts (lizards, squirrels). Nymphs feed on various mammals, including humans, which can act as dilution or reservoir hosts. ${ }^{38,118}$ Host descriptions in red refer to their importance for the pathogen, and host descriptions in black to their importance for the tick population. Red stars: no infection takes place; green stars: ticks can get infected with spirochetes. Arrows with a plus sign show a positive influence, and arrows with a minus sign a negative influence.

Abbreviations: $\mathrm{T}$, temperature; $\mathrm{RH}$, relative humidity. 
nymphs in those patches. LoGuidice et $\mathrm{al}^{28}$ further support the hypothesis by identifying important dilution (squirrels Tamiasciurus hudsonicus, Sciurus carolinensis) and rescue (shrews - Blarina spp., Sorex spp.) hosts. Ogden and Tsao ${ }^{29}$ used a model to describe the way in which the transmission of B. burgdorferi s.s. from I. scapularis ticks among mice is affected by increasing or decreasing the abundance of a less competent reservoir host. The model indicated that both a dilution and a rescue effect might occur, depending on such factors as host contact rate with ticks, potential acquired resistance in reservoir hosts, and competition.

A recent study from Brisson et $\mathrm{al}^{30}$ calls into question the formal belief that $P$. leucopus are the most important hosts for tick larvae and reservoir hosts of Borrelia spirochetes in the eastern USA. Using both ecological and molecular data, they were able to show that mice provide the blood meal for only approximately $10 \%$ of larvae found in the field and that chipmunks and shrews (feeding $35 \%$ of all ticks and 55\% of infected ticks) play a more important role in the enzootic cycles of Lyme disease than previously believed.

The situation with the main hosts of adult I. scapularis is more complex. Although deer are not competent vectors of B. burgdorferi s.s., and seem to have little or no role in the maintenance of infection in ticks, ${ }^{31}$ deer are the most important hosts for the female ticks and are therefore positively correlated with tick population dynamics. ${ }^{32,33}$ Historical data indicate that in the absence of deer, the populations of I. scapularis crash dramatically, ${ }^{34,35}$ and that the recent expansion of deer populations is associated with the range expansion not only of I. scapularis but also of Lyme disease incidence. ${ }^{36}$ Thus, although it seems that deer act as dilution hosts when it comes to the transmission of Borrelia spirochetes, they also act as a major host for reproductive I. scapularis females, and therefore as an amplifying host for tick populations (Figure 1). This increase in tick density also leads to an increased risk of infection for humans as shown in studies by Rand et $\mathrm{al}^{37}$ on Monhegan Island. Monhegan Island near the coast of Maine, USA, was populated by white-tailed deer and Norway rats (Rattus norvegicus), the latter being a competent reservoir for the Lyme disease spirochetes. When deer were removed from the island, the density of adult-questing ticks as well as of immature ticks on rats decreased significantly on a long-term basis compared to an island where deer were not removed. Thus, the health risk for humans was also reduced.

In addition to direct host-parasite interactions, Levi et $\mathrm{al}^{38}$ developed a theoretical model implying the importance of small mammal predators in the epidemiology of Lyme disease. The model suggested that the increase in Lyme disease cases in the northeastern and Midwestern USA over the last 30 years was not correlated with an increase in deer abundance but with the decline of red fox (Vulpes vulpes) populations due to the increased abundance of coyotes (Canis latrans) and therefore the increase in small mammal density.

Taken together, all of the studies discussed above show clearly how complex Lyme disease epidemiology is and that much more research is needed to fully understand the mechanisms underlying the system.

Although the epidemiology of Lyme disease in the USA is already complex, it is certainly less complex than the situation in Europe and Asia. While B. burgdorferi s.s. is the dominant agent for Lyme disease in the New World - other potential human pathogenic genospecies such as Borrelia bissetti are discussed ${ }^{39}$ - in Europe, at least five different genotypes of the B. burgdorferi s.l. complex are known to cause Lyme disease in humans. ${ }^{40}$ These human pathogenic agents include Borrelia afzelii, B. burgdorferi s.s., Borrelia garinii, Borrelia spielmanii, and Borrelia bavariensis, ${ }^{40}$ with the three former species being the most important both in Europe and Asia. ${ }^{41}$ The pathogenicity of other genospecies such as B. bissetti, Borrelia lusitaniae, or Borrelia valaisiana is still uncertain.

Not only are the different genospecies associated with different clinical manifestations, but they are also associated with different reservoir hosts and different vector species, either bridge vectors that transmit B. burgdorferi s.1. to humans or other vectors that act to maintain the pathogen in the enzootic cycles. ${ }^{39}$ B. afzelii often causes skin pathology such as chronic skin lesions or acrodermatitis chronica atrophicans ${ }^{42}$ and uses rodents as reservoir hosts. ${ }^{43,44}$ B. garinii is often associated with neuroborreliosis ${ }^{42}$ and uses different bird species as reservoir hosts. ${ }^{44-46}$ B. burgdorferi s.s. is often found in arthritic manifestations of the disease ${ }^{42}$ and seems not to be host specific as it is found in both bird and rodent enzootic cycle. ${ }^{44,46}$

In Europe, the most important bridge vector is the castor bean tick, Ixodes ricinus, which can adapt to a variety of different habitats ${ }^{47}$ and as a generalist feeds on over 300 different host species. ${ }^{48,49}$ In general, host communities in Europe consist of more than one dominant host species with good reservoir competence such as the yellow-necked mouse Apodemus flavicollis and the bank vole Myodes glareolus. Both provide blood meals for larvae and to a certain extent also to nymphs of $I$. ricinus, as well as serving as competent reservoir hosts for B. burgdorferi s.1. ${ }^{50,51}$ However, bank 
voles are able to acquire resistance to I. ricinus resulting in reduced feeding and molting success and reduced survival of the ticks, ${ }^{52}$ while $A$. flavicollis can acquire some immunity against Borrelia infection. ${ }^{53}$ This complicates our understanding of the enzootic cycle of Lyme disease.

Additionally to rodents, other medium-sized animals, although lower in abundance than rodents and shrews, can carry more ticks than smaller hosts and might play a greater role as a source of infection than mice and voles in some habitats. ${ }^{54}$ European hedgehogs (Erinaceus europaeus), for example, can be infected with B. burgdorferi s.l. and can also pass these infections on to both I. ricinus and the hedgehog tick Ixodes hexagonus. ${ }^{55-58}$ Therefore, when more than one equally competent reservoir host exists in the same community, each reservoir species can contribute to the rescue effect, and even though there are strong population fluctuations of one species, the other species can maintain the overall prevalence of the pathogen. ${ }^{16}$ In Europe, I. ricinus nymphs and adults also feed on deer, predominantly roe deer (Capreolus capreolus), red deer (Cervus elaphus), and fallow deer (Dama dama). ${ }^{59}$ Those wild ungulates are known to be non-reservoir hosts for B. burgdorferi s.1. ${ }^{60}$; however, they are important for providing blood meals for ticks, and therefore their reproduction and development. ${ }^{61}$ Unfortunately, there are no studies in Europe that clearly point out the role of wild ungulates in the epidemiology of Lyme disease.

For the European Lyme disease system, there is not one study that supports the dilution effect hypothesis and the positive influence of biodiversity on the infection risk to humans. The reason for this is not that the hypothesis cannot be applied to the system but simply that there have been no studies done to test this phenomenon. Of course, it is reasonable to assume that an increase in non-reservoir hosts decreases the contact rate of a potential vector with, and the transmission rate of a pathogen to, a reservoir host. But without studies on this subject, it is impossible to say whether this might happen in habitats with more complex disease systems, with more than one reservoir host, with a high density of amplification hosts, and if these effects even play an important role for the disease transmission or whether other factors, such as temperature, saturation deficit, or relative humidity, which are well known to influence the activity and the development of ticks (Figure 1), ${ }^{47}$ are more important for this system.

\section{Birds, mosquitos, and West Nile virus}

Another host-vector-pathogen system which has been studied in detail with respect to the dilution effect is that of birds, mosquitos, and the West Nile virus (WNV) (Figure 2).
WNV is maintained through enzootic cycles worldwide. The predominant vectors are mosquitos of the genus Culex. ${ }^{62}$ Although the virus has been isolated from other mosquito genera, their vector competence is not yet fully understood. ${ }^{63}$ WNV is a neuropathogen of birds, equines, and humans with the avian reservoir host belonging predominantly to the order Passeriformes. These are responsible for maintaining the primary enzootic cycle. ${ }^{62,64,65}$ Most cases of WNV infections are asymptomatic, while 15\%-20\% develop a flu-like illness with light fever, headache, malaise, anorexia, nausea, and vomiting. ${ }^{64}$ In less than $1 \%$ of the cases, a meningitis, meningoencephalitis, or myelitis accompanied by a high fever develops. ${ }^{66}$ Other symptoms or manifestations such as ataxia, extrapyramidal signs, polyradiculitis, seizures, optic neuritis, muscle weakness, hepatitis, pancreatitis, or myocarditis might occur. ${ }^{67-73}$

The virus was first isolated from the blood of a woman from the West Nile district, Uganda, in $1937 .{ }^{74}$ Thirteen years later, it was isolated from children in Egypt and from that point on, more and more isolates, mostly from birds, humans, and mosquitos, were obtained from throughout Africa, the Middle East, Asia, and Europe. ${ }^{75}$ Infrequent outbreaks of WNV were observed until the mid-1990s, but

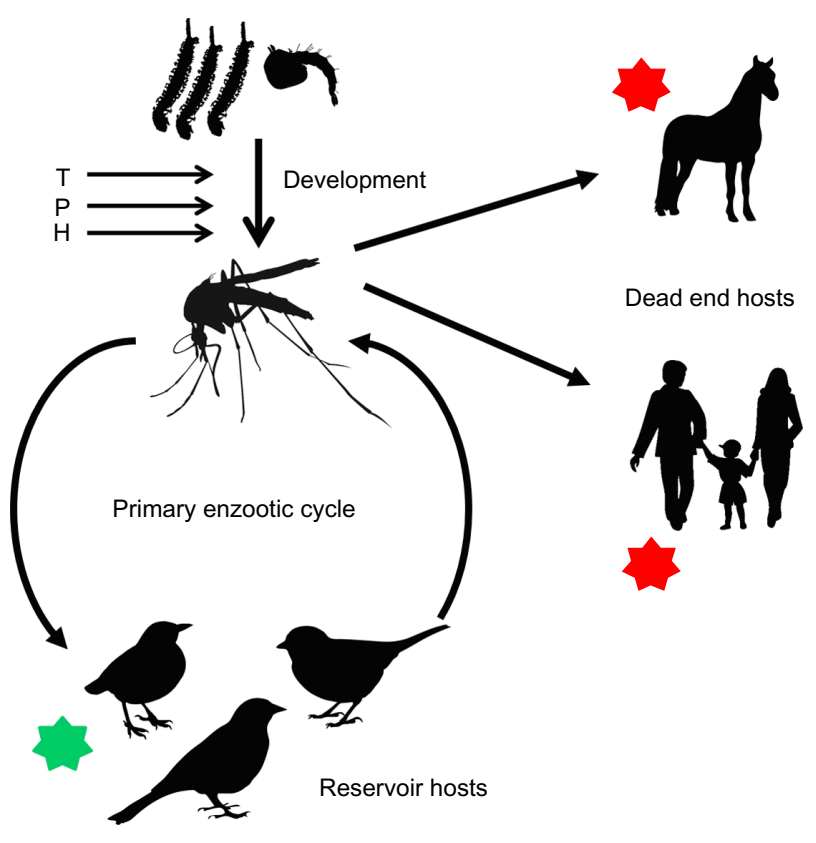

Figure 2 Eco-epidemiology of WNV.

Notes: Main vectors of WNV are mosquitos of the genus Culex. The primary enzootic cycle persists between mosquitos and passerine birds, which act as reservoir and amplifying hosts for the virus (green star). Infected mosquitos can transmit the virus to equines and humans, which can develop disease symptoms but cannot pass the infection to mosquitos or other hosts (red stars). The development of the mosquito vector and hence its population density is influenced by ambient temperature, precipitation, and habitat characteristics such as soil moisture, topography, and surface water. ${ }^{119}$

Abbreviations: WNV, West Nile virus; $\mathrm{T}$, temperature; $\mathrm{P}$, precipitation; $\mathrm{H}$, habitat. 
after this, certain epidemiological changes occurred leading to an increase in frequency of the outbreaks in humans and horses, an increase in the severity of human cases, and a high mortality in birds during the human outbreaks in Israel and the USA in 1999 and 2000. ${ }^{76}$

The intensity of transmission of WNV depends on both the abundance of competent vectors and their prevalence of infection, although some epidemiological outbreaks in the USA were linked to very low minimum infection rates in different Culex spp. ${ }^{77}$ Human infections occur when conditions benefit the amplification of the virus in birds and mosquitos, leading to a spillover to other host groups. ${ }^{18} \mathrm{With}$ passerine birds being competent and nonpasserine birds being less competent reservoirs for WNV, but representing a suitable blood meal for mosquitos, a dilution effect should result from a high species richness of the latter, causing a reduced rate at which the vectors acquire an infection, and therefore a reduced prevalence of WNV in mosquitos and thus fewer human cases.

Enzenwa et $\mathrm{al}^{18}$ tested for relationships between host diversity and the potential WNV transmission risk to humans on smaller and broader scales in the USA. They conducted their study at six field sites with varying land cover, including forest, marshland, wetlands, open water, and residential buildings. They collected mosquitos, measured avian species richness, and related the data gained with data on human WNV cases for the different counties. Infection rates in Culex mosquitos and the density of infected mosquitos were negatively correlated with the species richness and the abundance of nonpasserine birds, while they were neither positively nor negatively correlated with the species richness of passerine birds. WNV incidence in humans also correlated negatively with nonpasserine species richness. These findings indicate a dampening effect of nonpasserine birds on infection rates among mosquitos and humans, thus supporting the dilution effect hypothesis. Nevertheless, on a broader scale, nonpasserine species richness could only explain $27 \%$ of the variance in human cases compared to $79 \%-92 \%$ of the variance in mosquito infections across the six study sites. ${ }^{18}$

The degree of heterogeneity in a host population is an important aspect for disease transmission, since only a small part of the host community is responsible for the majority of disease transmission. ${ }^{78,79}$ Heterogeneity develops either through the variability of contact rates between hosts or between hosts and vectors or through the variability in the reservoir competence of hosts. ${ }^{80}$ Therefore, the composition of a host community plays an important role in disease epidemiology. To determine the primary host species for
WNV, Kilpatrick et al ${ }^{80}$ studied mosquito feeding patterns and the epidemiology of WNV in urban and residential areas in the USA. The American robin (Turdus migratorius) made up only $3.7 \%$ of the avian abundance at the test sites; however, it accounted for around $43 \%$ of mosquito feedings, showing a clear feeding preference of the mosquitos. Additionally, this species seemed to be responsible for the majority of WNV infections in mosquitos, acting as a super-spreader for this pathogen, while other passerine species, such as house sparrows (Passer domesticus) or corvids (in this study Corvus ossifragus), which were thought to play a primary role in the epidemiology of WNV, ${ }^{81,82}$ seemed to be less important. This indicates that WNV transmission is likely to be intense in certain host subgroups, but less intense in others, which leads to a high variability in WNV exposure for the different host species. ${ }^{80}$ As a result, the abundance of bird species, eg, the abundance of passerine and nonpasserine birds, seems to be a poor indicator of the relative importance of each species in WNV transmission.

Most studies on the effect of biodiversity on WNV transmission and incidence were done in the USA ${ }^{18,80,83,84}$ with the pathogen having been introduced only in 1999. Comparable studies from the native habitats of this pathogen are, however, surprisingly rare. As for Lyme disease, it is therefore hard to predict whether the dilution effect is of importance for WNV in its original habitats.

\section{Biodiversity and other disease systems}

As shown earlier, observed relationships between the loss of biodiversity and infections with vector-borne disease exist, and studies suggest that an increase in or conservation of biodiversity might reduce disease risk for humans. Although the dilution effect hypothesis is based on vector-borne disease, it can also be applied to other disease systems, with the rodent-hantavirus system being one of the most thoroughly investigated.

\section{Mice and hantavirus}

Hantavirus is a separate virus genus within the Bunyaviridae, representing at least 45 different species throughout the world, with high representation in temperate zones and with at least 22 "species" being pathogenic to humans. ${ }^{85,86}$ They can cause different diseases such as hemorrhagic fever with renal syndrome (HFRS) and hantavirus pulmonary syndrome (HPS). Around 150,000-200,000 people are hospitalized each year with HFRS worldwide, and although cases of HPS are rarer, the fatality rate is around $40 \%{ }^{87,88}$ The viruses are natural pathogens of small rodents (Muridae) and insecti- 
vores (Soricidae, Talpidae). They are usually transmitted to humans via aerosols of contaminated excreta such as saliva, urine, or feces. ${ }^{86,89-92}$ In addition, they can also be transmitted by the bites of infected host animals as well as indirectly via mites. ${ }^{85}$

The Sin Nombre virus (SNV) was the first hantavirus discovered in America. The common main host for the virus is the deer mouse (Peromyscus maniculatus).$^{93}$ In contrast to the dilution effect hypothesis of Ostfeld and Keesing ${ }^{16,17}$ in which the prevalence of tick infection is reduced due to the increase in species of unsuitable reservoir hosts leading to a reduced probability of infection of susceptible ticks, Peixoto and Abramson ${ }^{93}$ showed a different phenomenon in a mathematical model for SNV. The infection prevalence of the virus host is negatively affected by the presence of noninfected competitors, which exert a pressure on the whole host population, and the infected subpopulation may be reduced and even go extinct. Dizney and Ruedas ${ }^{94}$ examined 17 different ecological variables, associated with the prevalence of SNV and its prevalence in P. maniculatus, including different vegetation measurements. Only species diversity was connected to prevalence rates in reservoir hosts, with a decreasing species diversity leading to an increase in SNV prevalence. In a longterm study in Montana, USA, Carver et al ${ }^{95}$ collected 14 years of data on live-trapped small mammals from three field plots and estimated the standing antibody prevalence (ESPA) to SNV in deer mice. They found a negative relationship between the presence of voles and the ESPA of deer mice.

As for Lyme disease, there is also evidence available that indicates the important role of predators, as well as environmental factors, on the infection rate of hantavirus reservoir hosts. Orrock et $\mathrm{al}^{96}$ studied the prevalence of SNV in island deer mice on eight California Channel Islands. SNV prevalence was higher on islands with higher precipitation, greater area, and fewer species of rodent predators. This study accents the importance of taking into account both abiotic and biotic factors when studying disease ecology, since they are tightly connected and influence each other at various levels. The model of Peixoto and Abramson ${ }^{93}$ can be applied to different hantavirus-rodent systems in which one rodent species acts as a reservoir host and several other species, which cannot be infected, act as resource competitors to the virus host. The model is supported by a study from Suzán et $\mathrm{al}^{97}$ from Panama, who manipulated the species richness of common competent (northern pygmy rice rat Oligoryzomys fulvescens, common cane mouse Zygodontomys brevicauda) and non-competent reservoir hosts of the hantaviruses Choclo and Calabazo in experimental field plots. O. fulvescens and
Z. brevicauda represent the dominant species in deforested areas close to human settlements in Panama, ${ }^{98}$ and therefore, they play an important role in the transmission of hantaviruses to humans. To mimic natural patterns of species diversity loss, non-competent species were removed from some of the field plots. In the manipulated field plots where non-competent reservoirs were removed, the prevalence of hantavirus infections in wild reservoirs, as well as reservoir population densities, increased.

In an earlier study, ${ }^{99}$ differences in small mammal communities were linked with HPS incidence in the Azuero region, Panama. The faunal communities in areas where Choclo and Calabazo virus were present or HPS cases occurred were low in biodiversity compared to the control sites, supporting the dilution effect hypothesis.

Puumala virus (PUUV) is the major cause of HFRS in northern and continental Western Europe and is related to the distribution of its reservoir host the bank vole (M. glareolus). ${ }^{100}$ A study in Belgium on PUUV at 14 field sites revealed that the PUUV prevalence in $M$. glareolus was strongly, negatively correlated with the abundance of nonreservoir wood mice (Apodemus sylvaticus). ${ }^{101}$

\section{Further disease systems}

Schistosomiasis is a disease of the urinary tract or the intestines affecting approximately 207 million people worldwide. ${ }^{102}$ The disease agent is a trematode with a complex life cycle including freshwater snails as intermediate hosts and humans as definite hosts. The humans become infected through free-living parasite stages (miracidia, cercaria). Previous studies have shown that a high density of non-suitable hosts reduces the ability of the free-living life stages of these trematodes to find a suitable host. The interference caused by these non-suitable hosts varies among non-host species with the introduction of such hosts into a community causing either an increase or a decrease in cercarial production in suitable hosts. ${ }^{103}$ The reasons for this can be parasite exhaustion, penetration of the wrong host species, the production of toxins, or the stimulus of host immune defenses. ${ }^{104}$

Johnson et $\mathrm{al}^{103}$ experimentally evaluated the effect of the structure of the intermediate host community on transmission risk of Schistosoma mansoni, the agent of intestinal schistosomiasis, to humans. For their experiments, they used one suitable intermediate host (Biomphilaria glabrata) and two non-suitable snail hosts (Helisoma trivolvis, Lymnaea stagnalis). They conducted a $2 \times 2 \times 2$ factorial experiment in which parasite exposure and the presence of unsuitable hosts were manipulated. The experiments were either monospecific 
with one individual of $B$. glabrata or heterospecific with either two individuals of B. glabrata and one individual of $H$. trivolvis or L. stagnalis, respectively, or one individual of each species. Host density was never changed to avoid densitydependent changes in infection risk. The results showed that heterospecific communities caused a $20 \%-50 \%$ reduction in infection among suitable hosts, and infected suitable hosts that were raised with non-suitable hosts produced $60 \%-80 \%$ fewer cercariae. Since host density was not manipulated, these results clearly emphasize the importance of the community structure in disease systems. The only critical point of this study was the choice of non-suitable hosts. Although both Helisoma spp. and Lymnea spp. co-occur in the natural habitat of B. glabrata and S. mansoni, the particular species used in this study do not exist there.

Ribeiroia ondatrae is a multi-host parasitic trematode linked to amphibian limb transformations that negatively influence the survival of affected animals. ${ }^{105,106}$ The first intermediate hosts are pulmonate snails; the second are fish and larval amphibians including frogs, toads, and salamanders. ${ }^{107,108}$ In a laboratory experiment, Johnson et al ${ }^{109}$ exposed larval amphibians in mono- and heterospecific communities and varied host numbers in order to distinguish between density-dependent and diversitydependent effects on transmission. Ribeiroia infections lead to increased mortality and limb malformation rate in monospecific communities in toads (Bufo americanus), which are competent hosts for the parasite. In contrast, in heterospecific communities, with the presence of eastern gray tree frogs (Hyla versicolor) acting as decoy hosts, toads showed lower mortality and malformation rates. This clearly demonstrates the importance of community structure in determining parasite transmission and the resulting pathology in competent hosts.

To include potential predators and alternative hosts of parasites in the disease system, Orlofske et al ${ }^{110}$ used data from natural wetlands to investigate how such species mediate infection rates in a sensitive host species, the Pacific tree frog Pseudacris regilla. Four out of seven predatory species, including mollusks, zooplankton, fish, and larval insects, removed $62 \%-93 \%$ of the infectious trematode stages. Damselfly nymphs (predators) and newts (alternative hosts) reduced trematode infection in $P$. regilla by up to $50 \%$. Additionally, predators seemed to consume trematode stages even in the presence of alternative prey. This study is an example of the complexity of host-parasite or host-disease systems, showing that studying just one component will not show the whole picture.
The amphibian chytrid fungus Batrachochytrium dendrobatidis is responsible for amphibian population declines and extinctions worldwide. ${ }^{111}$ The spherical thalli of the fungus infect the keratinized cells of amphibians. Its ability to tolerate temperatures down to $4^{\circ} \mathrm{C}$ enables the fungus to overwinter in its host. ${ }^{111}$ To study the effect of biodiversity on the disease dynamics of $B$. dendrobatidis, Searle et al ${ }^{112}$ collected and reared eggs from different amphibian species with differing susceptibility to the fungus. As the susceptible species, which is known to have suffered population declines caused by $B$. dendrobatidis, they chose the western toad (Anaxyrus boreas). The other species included cascades frogs (Rana cascadae) and $P$. regilla, which can be sympatric with $A$. boreas and are less susceptible to fungal infection. The larvae of these species aggregate at high densities either in single-species or mixed-species schools, what makes them ideal to study the effect of density-dependent as well as species-dependent infection risk. In laboratory experiments, the densities of $A$. boreas and the other species present in different tanks were manipulated. Increased biodiversity led to a reduced disease risk for $A$. boreas, independently of the density of the toad. Those results show how community structure might influence disease transmission risk in an ecosystem. They also demonstrate the critical importance of laboratory work in determining the mechanisms leading to the dilution effect.

Another fungal disease system is that of the fungal parasite Metschnikowia bicuspidate infecting gammarids. In small freshwater lakes in Michigan, USA, the gammarid Daphnia dentifera acts as a host for the fungus. It becomes infected by consuming fungal spores, previously released from dead Daphnia. The infected Daphnia produce a large number of new spores and are likely to die over the course of infection. ${ }^{113}$ While other Daphnia spp. such as Daphnia pulicaria and Daphnia retrocurva can occur in the same habitat as D. dentifera and compete with it for algal resources, they are less suitable for $M$. bicuspidate. ${ }^{114,115}$ Additionally, they also graze on the fungal spores and can therefore reduce the infection risk for $D$. dentifera by removing the parasite. There are spatiotemporal variations in the size of epidemics in Midwestern US lakes, which might be partially influenced by the Daphnia community structure. Smaller epidemics were characterized by assemblages with higher numbers of unsuitable hosts, and within a season, less suitable hosts increased when epidemics declined. ${ }^{115}$ Detailed time series analysis of three epidemics by Hall et $\mathrm{al}^{115}$ showed a combination of the dilution effect and resource competition between Daphnia spp. with the net outcome of both interactions most likely determining the epidemics. 


\section{Overall conclusion}

We have presented various studies discussing the influence of biodiversity on disease transmission risk. The examples above clearly provide evidence that transmission risk to humans and other species can be reduced in communities with high biodiversity. However, work in this area is currently limited to only a few host-pathogen systems. Interestingly, the vast majority of the studies on this topic were conducted either in the Americas or by American researchers, while researchers from other parts of the world do not seem to have focused on this part of pathogen epidemiology. This leaves a big gap in our knowledge of disease systems in general. One reason is that it is not possible to apply the results from a system in one habitat to the system in another habitat. Additionally, abiotic and biotic factors (Figures 1 and 2), as well as anthropogenic influence, can vary significantly both temporarily and spatially. This is the case for WNV, for which studies on the influence of biodiversity on transmission risk were only conducted in the new range of the disease, while studies from the native ranges do not exist. Most studies presented here were field studies which based their evidence on correlations between certain factors, such as species richness or evenness, and disease incidence. However, it is well known that correlation does not imply causation, and in order to determine the role of certain factors, in this case biodiversity, it is necessary to manipulate the system; otherwise, it is almost impossible to clearly determine whether a measured effect is the result of coincidence, acts in a compensatory fashion, or is a real regulating process.

Experiments can be conducted in the field, where it is harder to control side effects resulting from climate, competition or predation influence, co-infections, and so on, or in the laboratory, which does not represent the natural environment of a system but can be more controlled and can show clear relationships between certain variables. Another option is the use of theoretical mathematical models in which various factors can be included or excluded and predictions for the development of disease systems can be made. However, one should not condemn or reduce the importance of field studies that do not manipulate the system just because they are based on limited probabilities and data sets. In fact, most data sets are limited, especially those collected in natural settings. This is based on the fact that comprehensive studies are hard to plan and conduct both due to the personnel needed and to the funding required. Nevertheless, the results from these studies provide important information and knowledge about disease systems, and they are currently our main window for observing such systems.
Where it is not possible to manipulate disease systems in the field or in laboratory studies, it is important to conduct long-term studies of at least 5 years in order to catch the natural fluctuations of suitable and non-suitable hosts, as well as vectors, and also the variables that affect them. This is especially important in the case of Lyme disease. The life cycle of the vector ticks I. scapularis or I. ricinus usually takes at least three or more years in their natural environment, ${ }^{116,117}$ depending on the availability of hosts for a blood meal and suitable environmental factors. Each developmental stage only feeds on one individual host animal, and therefore can transmit an infective agent only after molting to the next life history stage. This development can take up to a year. This means that the density of suitable reservoir hosts or infected larvae in 1 year is not representative of the density of infected nymphs or disease incidence in the same year. Furthermore, in the USA, mast years (eg, high production of acorns) strongly influence the density of mice, but most likely also of other host species (suitable and non-suitable for B. burgdorferi) in the following year. They therefore also influence the available host resources for ticks which again might benefit their development and the transmission of spirochetes. ${ }^{21}$ This means that at least 3 years of research are necessary to capture the influence of both abiotic factors and biotic factors on disease risk for Lyme disease in the northeastern USA. Furthermore, it shows that when examining a natural system, it is important to look at the whole picture, meaning that it is not enough to look just at suitable and non-suitable hosts when it comes to disease transmission in relation to biodiversity, since they are not the only limiting factor regarding transmission risk. Rather, it is important to include those factors that drive and influence biodiversity such as predators, competitors, resource availability, abiotic factors, and human activity. To cover this, it is indispensable to set up interdisciplinary projects with scientists from different research fields, including ecologists, epidemiologists, geoecologists, and climatologists. Only with such an effort will it be possible to develop adequate control and prevention plans to diminish human (and animal) disease risk in the future.

\section{Disclosure}

The authors report no conflicts of interest in this work.

\section{References}

1. Costanza R, Mageau M. What is a healthy ecosystem? Aquat Ecol. 1999;33:105-115.

2. United Nations. Convention on Biological Diversity; 1992. Available from: http://www.cbd.int/convention/text/default.shtml. Accessed July $27,2014$. 
3. Ostfeld R, Keesing F. Effects of host diversity on infectious disease. Annu Rev Ecol Evol Syst. 2012;43:157-182.

4. Mace GM, Norris K, Fitter AH. Biodiversity and ecosystem services: a multilayered relationship. Trends Ecol Evol. 2012;27:19-26.

5. Soliveres S, Smit C, Maestre FT. Effects of biodiversity on ecosystem functioning: a consensus of current knowledge. Ecol Monogr. 2005;75: 3-35.

6. Mouritsen KN, Poulin R. Parasitism as a determinant of community structure on intertidial flats. Mar Biol. 2010;157:201-213.

7. Knops JHM, Tilman D, Haddad NM, et al. Effects of plant species richness on invasion dynamics, disease outbreaks, insect abundances and diversity. Ecol Lett. 1999;2:286-293.

8. Sehgal RN. Biodiversity loss affects global disease ecology. Bioscience. 2009;59:945-954.

9. Thomas F, Renaud F, de Meeûs T, Poulin R. Manipulation of host behaviour by parasites: ecosystem engineering in the intertidal zone? Proc R Soc Lond B. 1998;265:1091-1096.

10. Mouritsen KN, Poulin R. Parasitism, community structure and biodiversity in intertidal ecosystems. Parasitology. 2002;124:101-117.

11. Kuris AM, Hechinger RF, Shaw JC, et al. Ecosystem energetic implications of parasite and free-living biomass in three estuaries. Nature. 2008;454:515-518.

12. Sala OE, Meyerson LA, Parmesan C. Changes in biodiversity and their consequences for human health. In: Sala OE, Meyerson LA, Parmesan C, editors. Biodiversity Change and Human Health: From Ecosystem Changes to Spread of Disease. Washington: Island Press; 2012:1-7.

13. Pimm SL, Russell GJ, Gittleman JL, Brooks TM. The future of biodiversity. Science. 1995;269:1466-1474.

14. Huynen MM, Martens P, De Groot RS. Linkages between biodiversity loss and human health: a global indicator analysis. Int J Environ Health Res. 2004;14:13-30.

15. Miller JR. Biodiversity conservation and the extinction of experience. Trends Ecol Evol. 2005;20:430-434.

16. Ostfeld R, Keesing F. Biodiversity and disease risk: the case of Lyme disease. Conserv Biol. 2000;14:722-728.

17. Ostfeld R, Keesing F. The function of biodiversity in the ecology of vector-borne zoonotic diseases. Can J Zool. 2000;78:2061-2078.

18. Enzenwa VO, Godsey MS, King RJ, Guptill SC. Avian diversity and West Nile virus: testing associations between biodiversity and infectious disease risk. Proc Biol Sci. 2006;273:109-117.

19. Keesing F, Belden LK, Daszak P, et al. Impacts of biodiversity on the emergence and transmission of infectious diseases. Nature. 2010;468:647-652.

20. Lyme Disease. Centers for Disease Control and Prevention. Available from: http://www.cdc.gov/lyme/stats/humanCases.html. Accessed October 7, 2014.

21. Ostfeld RS, Jones CG, Wolff JO. Of mice and mast. Bioscience. 1996;46:323-330.

22. Mather TN. The dynamics of spirochete transmission between ticks and vertebrates. In: Ginsberg HS, editor. Ecology and Environmental Management of Lyme Disease. New Brunswick: Rutgers University Press; 1993:43-60.

23. Van Buskirk J, Ostfeld RS. Controlling Lyme disease by modifying the density and species composition of tick hosts. Ecol Appl. 1995;5: $1133-1140$.

24. Van Buskirk J, Ostfeld RS. Habitat heterogeneity, dispersal, and local risk of exposure to Lyme disease. Ecol Appl. 1998;8:365-378.

25. Schmidt KA, Ostfeld RS, Schauber EM. Infestation of Peromyscus leucopus and Tamias striatus by the black-legged tick Ixodes scapularis (Acari: Ixodidae), in relation to the abundance of hosts and parasites. J Med Entomol. 1999;36:749-757.

26. Schmidt KA, Ostfeld RS. Biodiversity and the dilution effect in disease ecology. Ecology. 2001;82:609-619.

27. Allan BF, Keesing F, Ostfeld RS. Effect of forest fragmentation on Lyme disease risk. Conserv Biol. 2003;17:267-272.

28. LoGuidice K, Ostfeld RS, Schmidt KA, Keesing F. The ecology of infectious disease: effects of host diversity and community composition on Lyme disease risk. Proc Natl Acad Sci U S A. 2003;100:567-571.
29. Ogden NH, Tsao JI. Biodiversity and Lyme disease: dilution or amplification? Epidemics. 2009;1:196-206.

30. Brisson D, Dykhuizen DE, Ostfeld RS. Conspicuous impacts of inconspicuous hosts on the Lyme disease epidemic. Proc Biol Sci. 2008;275: 227-235.

31. Gray JS. The ecology of ticks transmitting Lyme borreliosis. Exp Appl Acarol. 1998;22:249-258.

32. Wilson ML, Adler G, Spielman A. Correlation between abundance of deer and that of the deer tick, Ixodes dammini (Acari: Ixodidae). Ann Entomol Soc Am. 1985;78:172-176.

33. Duffy DC, Campbell SR, Clark D, DiMotta C, Gurney S. Ixodes scapularis (Acari: Ixodidae) deer tick mesoscale populations in natural areas: effects of deer, area and location. J Med Entomol. 1994;31:152-158.

34. Steere AC. Lyme disease. N Engl J Med. 1989;321:586-596.

35. Sigal LH, Curran AS. Lyme disease: a multifocal worldwide epidemic. Annu Rev Public Health. 1991;12:85-109.

36. Piesmann J. Ecology of Borrelia burgdorferi sensu lato in North America. In: Gray J, Kahl O, Stanek G, editors. Lyme Borreliosis: Biology, Epidemiology and Control. Oxon, NY: CABI; 2002:223-249.

37. Rand PW, Lubelczyk C, Holman MS, Lacombe EH, Smith RP Jr. Abundance of Ixodes scapularis (Acari: Ixodidae) after the complete removal of deer from an isolated offshore island, endemic for Lyme disease. J Med Entomol. 2004;41:779-784.

38. Levi T, Kilpatrick AM, Mangel M, Wilmers CC. Deer, predators, and the emergence of Lyme disease. Proc Natl Acad Sci U S A. 2012;109: 10942-10947.

39. Rudenko N, Golovchenko M, Grubhoffer L, Oliver JH Jr. Updates on Borrelia burgdorferi sensu lato complex with respect to public health. Ticks Tick Borne Dis. 2011;2:123-128.

40. Stanek G, Reiter M. The expanding Lyme Borrelia complex - clinical significance of genomic species? Clin Microbiol Infect. 2011;17:487-493.

41. Hovius JWR, van Dam AP, Fikrig E. Tick-host-pathogen interactions in Lyme borreliosis. Trends Parasitol. 2007;23:434-438.

42. Strle F, Stanek G. Clinical manifestations and diagnosis of Lyme borreliosis. In: Lipsker D, Jaulhac B, editors. Lyme Borreliosis: Biological and Clinical Aspects. Basel: Karger-Verlag; 2009:51-110.

43. Humair P-F, Rais O, Gern L. Transmission of Borrelia afzelii from Apodemus mice and Clethrionomys voles to Ixodes ricinus ticks: differential transmission pattern and overwintering maintenance. Parasitology. 1999;118:33-42.

44. Kurtenbach K, Hanincova K, Tsao JI, Margos G, Fish D, Ogden NH. Fundamental processes in the evolutionary ecology of Lyme borreliosis. Nat Rev Microbiol. 2006;4:660-669.

45. Hanincová K, Taragelová V, Koci J, et al. Association of Borrelia garinii and B. valaisiana with songbirds in Slovakia. Appl Environ Microbiol. 2003;69:2825-2830.

46. Gern L. Borrelia burgdorferi sensu lato, the agent of Lyme borreliosis: life in the wild. Parasite. 2008;15:244-247.

47. Pfäffle M, Littwin N, Muders SV, Petney TN. The ecology of tick-borne diseases. Int J Parasitol. 2013;43:1059-1077.

48. Gern L, Humair P-F. Ecology of Borrelia burgdorferi sensu lato in Europe. In: Kahl O, Gray JS, Lane RS, Stanek G, editors. Lyme Borreliosis: Biology, Epidemiology and Control. Oxford: CABI Publishing; 2002:149-174.

49. Gern L. The biology of Ixodes ricinus. Ther Umsch. 2005;62:707-712.

50. Jensen TS. Seed-seed predator interactions of European beech, Fagus silvatica and forest rodents, Clethrionomys glareolus and Apodemus flavicollis. Oikos. 1985;44:149-156.

51. Humair P-F, Turrian N, Aeschlimann A, Gern L. Borrelia burgdorferi in a focus of Lyme borreliosis: epizootiologic contribution of small mammals. Folia Parasitol. 1993;40:65-70.

52. Dizij A, Kurtenbach K. Clethrionomys glareolus, but not Apodemus flavicollis, acquires resistance to Ixodes ricinus L., the main European vector of Borrelia burgdorferi. Parasite Immunol. 1995;17:177-183.

53. Kurtenbach K, Dizij A, Seitz HM, et al. Differential immune responses to Borrelia burgdorferi in European wild rodent species influence spirochete transmission to Ixodes ricinus L. (Acari: lxodidae). Infect Immun. 1994;62:5344-5352. 
54. Craine N, Randolph SE, Nuttall PA. Seasonal variations in the role of grey squirrels as hosts of Ixodes ricinus, the tick vector of Lyme disease spirochaete, in a British woodland. Folia Parasitol. 1995;42:73-80.

55. Gern L, Toutoungi LN, Chang MH, Aeschlimann A. Ixodes (Pholeoixodes) hexagonus, an efficient vector of Borrelia burgdorferi in the laboratory. Med Vet Entomol. 1991;5:431-435.

56. Gern L, Rouvinez E, Toutoungi LN, Godfroid E. Transmission cycles of Borrelia burgdorferi sensu lato involving Ixodes ricinus and/or I. hexagonus ticks in the European hedgehog, Erinacues europaeus, in suburban and urban areas in Switzerland. Folia Parasitol (Praha). 1997;44:309-314.

57. Skuballa J, Oehme R, Hartelt K, et al. European hedgehogs as hosts for Borrelia spp., Germany. Emerg Infect Dis. 2007;13:952-953.

58. Skuballa J, Petney T, Pfäffle M, et al. Occurence of different Borrelia burgdorferi sensu lato species including B. afzelii, B. bavariensis and B. spielmanii in hedgehogs (Erinaceus spp.) in Europe. Ticks Tick Borne Dis. 2012;3:8-13.

59. Matuschka FR, Heiler M, Eiffert H, Fischer P, Lotter H, Spielman A. Diversionary role of hoofed game in the transmission of Lyme disease spirochetes. Am J Trop Med Hyg. 1993;48:693-699.

60. Gern L, Estrada-Peña A, Frandsen F, et al. European reservoir hosts of Borrelia burgdorferi sensu lato. Zentralbl Bakteriol. 1998;287: 196-204.

61. Léger E, Vourc'h G, Vial L, Chevillon C, McCoy KD. Changing distributions of ticks: causes and consequences. Exp Appl Acarol. 2013;59: 219-244.

62. Kramer LD, Li J, Shi P-Y. West Nile virus. Lancet Neurol. 2007;6: $171-181$

63. Godsey MS Jr, Nasci R, Savage HM, et al. West Nile virus-infected mosquitoes, Louisianna, 2002. Emerg Infect Dis. 2005;11:1399-1404.

64. Campbell GL, Marfin AA, Lanciotti RS, Gubler DJ. West Nile virus. Lancet Infect Dis. 2002;2:519-529.

65. Trevejo RT, Eidson M. West Nile virus. J Am Vet Med Assoc. 2008;232: 1302-1309.

66. Zeller HG, Schuffenecker I. West Nile virus: an overview of its spread in Europe and the Mediterranean Basin in contrast to its spread in the Americas. Eur J Clin Microbiol Infect Dis. 2004;23:147-156.

67. Georges AJ, Lesbordes JL, Georges-Courbot MC, Meunier DMY, Gonzalez JP. Fatal hepatitis from West Nile virus. Ann Inst Pasteur Virol. 1987;138:237-244.

68. Ahmed S, Libman R, Wesson K, Ahmed F, Einberg K. Guillain-Barré syndrome: an unusual presentation of West Nile virus infection. Neurology. 2000;55:144-146.

69. Samspon BA,Ambrosi C, CharlotA, Reiber K, Veress JF, Armbrustmacher V. The pathology of human West Nile virus infection. Hum Pathol. 2000;31:527-531.

70. Weinberger M, Pitlik SD, Gandacu D, et al. West Nile fever outbreak, Israel, 2000: epidemiological aspects. Emerg Infect Dis. 2001;7: 686-691.

71. Burt FJ, Grobbelaar AA, Leman PA, Anthony FS, Gibson GVF, Swanepoel R. Phylogenetic relationships of southern African West Nile virus isolates. Emerg Infect Dis. 2002;8:820-826.

72. Klein C, Kimiagar I, Pollak L, et al. Neurological features of West Nile virus infection during the 2000 outbreak in a regional hospital in Israel J Neurol Sci. 2002;200:63-66.

73. Leis AA, Stokic DS, Polk JL, Dostrow V, Winkelmann M. A poliomyelitislike syndrome from West Nile virus infection. N Engl J Med. 2002;347: 1279-1280.

74. Smithburn KC, Hughes TP, Burke AW, Paul JH. A neurotropic virus isolated from the blood of a native of Uganda. Am J Trop Med Hyg. 1940;20:471-472.

75. Hayes CG. West Nile virus: Uganda 1937, to New York City, 1999. Ann NY Acad Sci. 2001;951:25-37.

76. Petersen LR, Roehrig JT. West Nile virus: a reemerging global pathogen. Rev Biomed. 2001;12:208-216.

77. Hayes EB, Komar N, Nasci RS, Montgomery SP, O’Leary DR, Campbell GL. Epidemiology and transmission dynamics of West Nile virus. Emerg Infect Dis. 2005;11:1167-1173.
78. Perkins SE, Cattadori IM, Tagliapietra V, Rizzoli AP, Hudson PJ. Empirical evidence for key hosts in persistence of a tick-borne disease. Int $J$ Parasitol. 2003;33:909-917.

79. Lloyd-Smith JO, Schreiber SJ, Kopp PE, Getz WM. Superspreading and the effect of individual variation on disease emergence. Nature. 2005;438:355-359.

80. Kilpatrick AM, Daszak P, Jones MJ, Marra PP, Kramer LD. Host heterogeneity dominates West Nile virus transmission. Proc Biol Sci. 2006;273:2327-2333.

81. Komar N, Panella NA, Burns JE, Dusza SW, Mascarenhas TM, Talbot TO. Serologic evidence for West Nile virus infection in birds in the New York city vicinity during an outbreak in 1999. Emerg Infect Dis. 2001;7:621-625.

82. Garvin MC, Tarvin KA, Smith J, Ohajuruka OA, Grimes S. Patterns of West Nile virus infection in Ohio blue jays: implications for initiation of the annual cycle. Am J Trop Med Hyg. 2004;70:566-570.

83. Swaddle JP, Calos SE. Increased avian diversity is associated with lower incidence of human West Nile infection: observation of the dilution effect. PLoS One. 2008;3(6):e2488. doi: 10.1371/journal. pone.0002488.

84. Allan BF, Langerhans RB, Ryberg WA, et al. Ecological correlates of risk and incidence of West Nile virus in the United States. Oecologia. 2009;158:699-708.

85. Bi Z, Formenty PBH, Roth CE. Hantavirus Infection: a review and global update. J Infect Dev Ctries. 2008;2:3-23.

86. Dearing MD, Dizney L. Ecology of hantavirus in a changing world. Ann N Y Acad Sci. 2010;1195:99-112.

87. Lee HW. Epidemiology and pathogenesis of haemorrhagic fever with renal syndrome. In: Elliot RM, editor. The Bunyaviridae. New York: Plenum Press; 1996:253-267.

88. Lednicky JA. Hantavirus: a short review. Arch Pathol Lab Med. 2003;127:30-35.

89. Yanagihara R, Amyx HL, Gajdusek DC. Experimental infection with Puumala virus, the etiologic agent of nephropathia epidemica, in bank voles (Clethrionomys glareolus). J Virol. 1985;55:34-38.

90. Gavrilovskaya IN, Apekina NS, Bernstehin AD, et al. Pathogenesis of hemorrhagic fever with renal syndrome virus infection and mode of horizontal transmission of hantavirus in bank voles. In: Calisher $\mathrm{CH}$, editor. Hemorrhagic Fever with Renal Syndrome, Tick- and MosquitoBorne Viruses. Vienna: Springer; 1991:57-62.

91. Kariwa H, Fujiki M, Yoshimatsu K, Arikawa J, Takashima I, Hashimoto N. Urine-associated horizontal transmission of Seoul virus among rats. Arch Virol. 1998;143:15-24.

92. Bernshtein AD, Apekina NS, Mikhailova TV, et al. Dynamics of Puumala hantavirus infection in naturally infected bank voles (Clethrinomys glareolus). Arch Virol. 1999;144:2415-2428.

93. Peixoto ID, Abramson G. The effect of biodiversity on the hantavirus epizootic. Ecology. 2006;87:873-879.

94. Dizney L, Ruedas LA. Increased host species diversity and decreased prevalence of Sin Nombre Virus. Emerg Infect Dis. 2009;15: 1012-1018

95. Carver S, Kuenzi A, Bagamian KH, et al. A temporal dilution effect: hantavirus infection in deer mice and the intermittent presence of voles in Montana. Oecologia. 2011;166:713-721.

96. Orrock JL, Allan BF, Drost CA. Biogeographic and ecological regulation of disease: prevalence of Sin Nombre Virus in island mice is related to island area, precipitation, and predator richness. Am Nat. 2011;177: 691-697.

97. Suzán G, Marcé E, Giermakowski JT, et al. Experimental evidence for reduced rodent diversity causing increased hantavirus prevalence. PLoS One. 2009;4(5):e5461. doi: 10.1371/journal.pone.0005461.

98. Suzan G, Armien A, Mills JN, et al. Epidemiological considerations of rodent community composition in fragmented landscapes in Panama. J Mammal. 2008;89:684-690.

99. Ruedas LA, Salazar-Bravo J, Tinnin DS, et al. Community ecology of small mammal populations in Panamá following an outbreak of hantavirus pulmonary syndrome. J Vector Ecol. 2004;29:177-191. 
100. Tersago K, Verhagen R, Vapalathi O, Heyman P, Ducoffre G, Leirs H. Hantavirus outbreak in Western Europe: reservoir host infection dynamics related to human disease patterns. Epidemiol Infect. 2011;139: 381-390.

101. Tersago K, Schreurs A, Linard C, Verhagen R, Van Dongen S, Leirs H. Population, environmental, and community effects on local bank vole (Myodes glareolus) Puumala virus infection in an area with low human incidence. Vector Borne Zoonotic Dis. 2008;8:235-244.

102. Fenwick A. The global burden of neglected tropical diseases. Public Health. 2014;126:233-236.

103. Johnson PTJ, Lund PJ, Hartson RB, Yoshino TP. Community diversity reduces Schistosoma mansoni transmission, host pathology and human infection risk. Proc Biol Sci. 2009;276:1657-1663.

104. Combes C, Moné H. Possible mechanisms of the decoy effect in Schistosoma mansoni transmission. Int J Parasitol. 1987;17:971-975.

105. Johnson PTJ, Lunde KB, Ritchie EG, Launer AE. The effect of trematode infection on amphibian limb development and survivorship. Science. 1999;284:802-804.

106. Johnson PTJ, Sutherland DR. Amphibian deformities and Ribeiroia infection: an emerging helminthiasis. Trends Parasitol. 2003;19: 332-335.

107. Johnson PTJ, Lunde KB, Haight RW, Bowerman J, Blaustein AR. Ribeiroia ondatrae (Trematoda: Digenea) infection induces severe limb malformations in western toads (Bufo boreas). Can J Zool. 2001;79:370-379.

108. Johnson PTJ, Lunde KB, Thurman EM, et al. Parasite (Ribeiroia ondatrae) infection linked to amphibian malformations in the western United States. Ecol Monogr. 2002;72:151-168.

109. Johnson PTJ, Hartson RB, Larson DJ, Sutherland DR. Diversity and disease: community structure drives parasite transmission and host fitness. Ecol Lett. 2008;11:1017-1026.

110. Orlofske SA, Jadin RC, Preston DL, Johnson PT. Parasite transmission in complex communities: predators and alternative hosts alter pathogenic infections in amphibians. Ecology. 2012;93:1247-1253.
111. Piotrowski JS, Annis SL, Longcore JE. Physiology of Batrachochytrium dendrobatidis, a chytrid pathogen of amphibians. Mycologia. 2004;96: 9-15.

112. Searle CL, Biga LM, Spatafora JW, Blaustein AR. A dilution effect in the emerging amphibian pathogen Batrachochytrium dendrobatidis. Proc Natl Acad Sci U S A. 2011;108:16322-16326.

113. Hall SR, Sivars-Becker L, Becker C, Duffy MA, Tessier AJ, Caceres CE. Eating yourself sick: transmission of disease as a function of foraging ecology. Ecol Lett. 2007;10:207-218.

114. Leibold MA, Tessier AJ. Habitat partitioning by zooplankton and the structure of lake ecosystems. In: Streit B, Städler T, Lively CM, editors. Evolutionary Ecology of Freshwater Animals. Basel: Birkhäuser Verlag; 1997:3-30.

115. Hall SR, Becker CR, Simonis JL, Duffy MA, Tessier AJ, Caceres CE. Friendly competition: evidence for a dilution effect among competitors in a planktonic host-parasite system. Ecology. 2009;90:791-801.

116. Robbin LL, Barker IK, Surgeoner GA, McEwen SA, Gillespie TJ, Addison EM. Survival and development of the different life stages of Ixodes scapularis (Acari: Ixodidae) held within four habitats on long point, Ontario, Canada. J Med Entomol. 1998;35:189-199.

117. Randolph SE, Green RM, Hoodless AN, Peacey MF. An empirical quantitative framework for the seasonal population dynamics of the tick Ixodes ricinus. Int J Parasitol. 2002;32:979-989.

118. Ostfeld RS, Canham CD, Oggenfuss K, Winchcombe RJ, Keesing F. Climate, deer, rodents, and acorns as determinants of variation in Lyme-disease risk. PLoS Biol. 2006;4(6):e145. doi: 10.1371/journal. pbio.0040145.

119. Paz S, Semenza JC. Environmental drivers of West Nile fever epidemiology in Europe and Western Asia - a review. Int J Environ Res Public Health. 2013;10:3543-3562.
Research and Reports in Biodiversity Studies

\section{Publish your work in this journal}

Research and Reports in Biodiversity Studies is an international, peerreviewed, open access journal publishing original research, reports, reviews and commentaries on all areas of biodiversity research. The manuscript management system is completely online and includes a

\section{Dovepress}

very quick and fair peer-review system. Visit http://www.dovepress.com/ testimonials.php to read real quotes from published authors. 